6 Bebbington PE, Sturt E, Tennant C, Hurry J. Misfortune and resilience: a community studs of women. Psychol hed 1984;14:347-63.

7 Hammen $C$. Depression and cognition about stressful life events. In Allov LB, ed Cognutre processes in depression. New York: Guildford Press, 1988 .

8 Kumar R, Rubson KM A prospective study of emotional disorders in childbearing women. Brf Psychiatry 1984;144:35-47.

O'Hara MW. Social support, life events and depression during pregnancy and the puerperium. Arch Gen Psychiatry 1986:43:569-73.

10 Trowell J. Possible effects of emergency caesarian section on the mother-child relationship. Early Hum Dev 1982;7:41-5

11 Grossman FK, Eichler LS, Winnickoff SA. Pregnancy, birth and parenthood: adaptation of mothers, fathers and infants. San Francisco: Jossey-Bass, 1980

12 Zajicek E. The experience of being pregnant. In: Wolkind S, Zajicek E, eds. Pregnancy: a psychological and social study. New York: Grune Stratton Academic Press, 198

3 Spillman JR. Emotional aspects of experiencing a multiple birth. Midwife, Health Visitor and Community Nurse 1987;23:54.

14 Spillman JR. Double exposure-coping with newborn twins at home. Midwife, Health Visitor and Community Nurse' 1984:20:92.

15 Sandbank AC. The effect of twins on family relationships. Acta Genet Med Gemellol (Roma) 1988:37:161-71

16 Scheinfield A. Twins and supertwins. Harmondsworth: Penguin, 1973.

17 Groothuis JR, Altemeier WA, Robarge JP, et al. Increased child abuse in fathilies with twins. Pediatrics 1982:70:769-73.

18 Goshen Gottstein ER. The mothering of twins, triplets and quadruplets. Psychiatry 1980;43:189-203.

19 Bryan EM. The loss of a twin. Maternal and Child Health 1983;May:201-6.

20 Freidrich L, Rowland C. The twins handbook. London: Robins, 1983.

1 Linney J. Multiple births. London: Routledge and Kegan Paul, 1983.

22 MacGillivray I, Campbell DM. Management of twin pregnancies. In: MacGillivray I, Campbell DM, Thompson B, eds. Twinning and twin Chichester: Wiley, 1988

23 Green J. Calming of harming? A critical review of psychological effects of fetal diagnosis of pregnant women. London: Galton Institute, March 1990. Occasional papers, second series, No 2.

24 Magnus P, Arntzen A, Samuelson SO, Halderson T, Bakketeig T. No correlation in post-neonatal deaths for twins. A study of the early mortality of twins based on the Norwegian medical birth registry. Early Hum Dev 1990;22:89-97.

25 Lewis E, Bryan EM. Management of perinatal loss of a twin. BMJ 1988:297:1321-2.

26 Dell'Avvocato L. Do we realise the stress caused by twins? Health Visitor 1988;61:37

27 Haigh J, Wilkinson L. Care and management of twins. Health Visitor 1989;62:43-5

28 Robin M, Josse D, Tourette C. Mother-twin interaction during early childhood. Acta Genet Med Gemellol (Roma) 1988;37:151-9.

29 Powell TJ. Symptoms of postnatal (atypical) depression in mothers of twins [MSc thesis] Surrey: Surrey University, 1981

30 Snaith RP, Bridge GWK, Hamilton M. The Leeds scales for the self assessment of anxiety and depression. Br f Psychiatry 1976;128:156-65.

31 Butler NR, Golding J. From birth to five: a study of health and behaviour of Britain's five veur olds. Oxford: Pergamon Press, 1986.

32 Nelson MHB, Martin CA. Increased child abuse in twins. Child Abuse and Neglect. 1985;9:501-5.

33 Tanimura M, Matsui I, Kobayashi N. Child abuse in one of a pair of twins in Japan. Lancet 1990;336:1298-9.

34 Rutter M, Tizard J, Whitmore K. Education, health and behaviour. London: Longman, 1980.

35 Brodman K, Erdmann AJ, Lorge I, Wolff HG, Broadbent TH. Cornell medical index: an adjunct to medical interview. FAMA 1949;140:530-4

36 Richman N. Depression in mothers of young children. $\mathcal{F} R$ Soc Med 1978;71:489-93.

37 Rutter M, Tizard J, Yule W, Graham P, Whitmore K. Isle of Wight Studies 1964-1974. Psychol Med 1976;6:313-32.

(Accepted 6 February 1991)

\title{
Routine examination in the neonatal period
}

\author{
G D Moss, P H T Cartlidge, B D Speidel, T L Chambers
}

Abstract

Objective-To assess the value of the second neonatal examination as a medical surveillance procedure.

Design-Prospective survey of routine neonatal examinations and the abnormalities identified during 8 March-30 June 1988.

Setting-Maternity unit with an annual birth rate of 5700 .

Subjects-For first neonatal examination: 1795 babies born in the unit during the $\mathbf{1 1 5}$ day observation period. For second routine examination: 1747 babies $(97 \cdot 3 \%)$ discharged from postnatal ward.

Main outcome measures-Missed abnormalities (present but not previously noted); minor abnormalities (superficial infection or trivial or transient abnormalities not requiring intervention); and important abnormalities (unlikely to have been present at first examination but requiring intervention).

Results-An abnormality was detected in 158 $(8.8 \%)$ infants on first neonatal examination. 1428 (79.6\%) babies had a routine second examination, which disclosed 63 previously undetected abnormalities. Of these, seven $(11 \%)$ would have been present on first examination, $49(78 \%)$ were considered minor, and seven (11\%) important - the most consequential being dislocatable hips (four infants). Thus an important finding was detected by only $0.5 \%$ of second examinations.

Conclusions - A second thorough examination in the early neonatal period cannot be justified as a screening procedure. A repeat examination of the hips alone in the first week of life is necessary.

\section{Introduction}

The report of the Joint Working Party on Child Health Surveillance ${ }^{1}$ suggests that each neonate should receive a thorough physical examination within 24 hours after birth with a repeat examination of the hips on discharge from hospital or within 10 days after birth but no further routine examination until the age of 6 weeks. This contrasts with previous guidelines, which recommended a second full examination, before discharge, for all those babies remaining in hospital for more than two or three days. ${ }^{2}$ The value of an initial neonatal examination is widely accepted, but there is little information concerning the previously recommended second neonatal examination to either support or refute its exclusion from the core programme for child health surveillance proposed by the Hall report.

We recently reviewed the practice of routine neonatal examinations within our maternity unit. We present our results with particular reference to the second neonatal examination to provide information on its value as a medical surveillance procedure.

\section{Subjects and methods}

Details of the routine examinations of neonates performed by our senior house officers were collected prospectively from the case notes of all the 1795 babies born during 115 days from 8 March to 30 June 1988. These case notes were already being routinely scrutinised by the registrar so it was therefore possible to collect data without drawing the attention of the senior house officers to the study. The policy of the unit was that babies were fully examined within 24 hours after birth and again on the day of discharge. The second examination was omitted only in those babies discharged within 18 hours after birth and in some babies discharged at a weekend, provided that they had received a full examination in the 24 hours before going home.

All abnormalities identified were recorded. Unfortunately, we were unable to ascertain from the case notes whether parents or nursing or medical staff were the first to discover the abnormality. Any abnormalities detected on the second examination which had not been previously noted were classified as: missed abnormalities - that is, those that would have been present but were not previously noted; minor abnormalities-that is, superficial infection or trivial or
Correspondence to: Dr Moss.

BMF 1991;302:878-9 


\begin{tabular}{lr}
\hline & $\begin{array}{r}\text { No of } \\
\text { babies }\end{array}$ \\
\hline Orthopaedic & 44 \\
Respiratory & 24 \\
Cardiovascular & 17 \\
Dermatological & 12 \\
Urological & 11 \\
Birth trauma & 11 \\
Ear, nose, and throat & 8 \\
Maternal problems & 8 \\
Chromosomal abnormality & 4 \\
Jaundice & 4 \\
Ophthalmological & 2 \\
Neuromuscular & 1 \\
Gastrointestinal & 1 \\
Miscellaneous & 11 \\
\hline Total & 158 \\
\hline
\end{tabular}

TABLE II - Timing of second examination in 1428 infants

\begin{tabular}{cc}
\hline $\begin{array}{c}\text { Postnatal age } \\
\text { (days) }\end{array}$ & No of babies \\
\hline 1 & 17 \\
2 & 355 \\
3 & 305 \\
4 & 320 \\
5 & 230 \\
6 & 100 \\
7 & 52 \\
8 & 21 \\
9 & 17 \\
10 & 5 \\
11 & 4 \\
12 & 2 \\
\end{tabular}

TABLE III-Previously undetected abnormalities found on second examination

\begin{tabular}{lr}
\hline Abnormality & $\begin{array}{r}\text { No of } \\
\text { babies }\end{array}$ \\
\hline \multicolumn{1}{c}{ Missed abnormality $(n=7)$} \\
Requiring intervention: \\
$\quad$ Vestigial digit \\
$\quad$ Coloboma of iris \\
$\quad$ Maternal history of \\
$\quad$ thyrotoxicosis \\
Not requiring intervention: \\
$\quad$ Positional talipes \\
Pigmented naevus \\
Pre-auricular skin tag \\
$\quad$ Minor abnormality $(n=49)$ \\
Infection & 1 \\
Jaundice & 1 \\
Cephalhaematoma & 30 \\
Cardiac murmur & 9 \\
Other & 5 \\
$\quad$ Important abnormality $(n=7)$ \\
Dislocatable hip & 4 \\
Jaundice & 1 \\
Cardiac murmur & 1 \\
Distended abdomen & 1 \\
\hline
\end{tabular}

transient abnormalities not requiring intervention; or important abnormalities - that is, those unlikely to have been present on the first examination and whose detection led to intervention requiring the baby to stay in hospital or to receive outpatient follow up, or both.

\section{Results}

FIRST NEONATAL EXAMINATION

The initial neonatal examination was performed within 24 hours after birth in $1635(91.0 \%)$ infants and within 48 hours in $1781(99 \cdot 2 \%)$. Abnormalities were detected in 158 infants $(8 \cdot 8 \%)$, the most common being orthopaedic problems (table I).

\section{SECOND NEONATAL EXAMINATION}

A second routine examination was performed on the proposed day of discharge on 1428 infants $(79 \cdot 6 \%)$. It was omitted in 319 babies for the reasons already outlined. Forty eight further babies were discharged from the special care baby unit, transferred to another unit for medical reasons, or died before leaving hospital. The second examination was performed between the 1st and 12th day of life (median day 4), with $372(26 \%)$ of examinations occurring on or before the second day and $677(47 \%)$ on or before day 3 (table II).

The second examination disclosed 63 abnormalities not previously noted (table III). Superficial infection in 30 infants was the most common abnormality (conjunctivitis (22 infants), paronychia (five), septic spots (two), and discharging ear (one)) and was treated with a topical or oral antibiotic in $22(73 \%)$. Jaundice severe enough to prompt measurement of serum bilirubin concentration was present in nine infants, but treatment was not necessary in any of them. Four infants had cardiac murmurs which were transient, and they were not followed up as outpatients.

Important abnormalities were found in seven infants. The most common was a congenitally dislocatable hip found in four infants; two infants received splintage and all hips were clinically and radiologically normal at 1 year of age. An otherwise well infant born at term, who was noted to be jaundiced on day 3 , was detained and given phototherapy on day 4 , although in retrospect

TABLE IV-Timing of detection of previously undetected abnormalities noted on second examination

\begin{tabular}{cccc}
\hline & \multicolumn{3}{c}{ No of babies with: } \\
\cline { 2 - 4 } $\begin{array}{c}\text { Postnatal age } \\
\text { (days) }\end{array}$ & $\begin{array}{c}\text { Missed } \\
\text { abnormality }\end{array}$ & $\begin{array}{c}\text { Minor } \\
\text { abnormality }\end{array}$ & $\begin{array}{c}\text { Important } \\
\text { abnormality }\end{array}$ \\
\hline 2 & 3 & 5 & \\
3 & 2 & 9 & 3 \\
4 & 1 & 12 & 3 \\
5 & & 16 & 1 \\
6 & 1 & 4 & \\
7 & & 1 & \\
8 & & 2 & \\
\hline
\end{tabular}

this was unnecessary (serum bilirubin concentration $280 \mu \mathrm{mol} / \mathrm{l}$ ). A cardiac murmur, which was still present on discharge, was heard in an otherwise normal baby; no symptoms developed and the murmur resolved by the age of 3 months. One baby had a distended abdomen; abdominal $x$ ray examination and serum immunoreactive trypsin assay showed normal findings, and the baby was well and thriving at 1 month of age. All important abnormalities were detected by examinations performed between the 3rd and 5th day of life (table IV).

\section{Discussion}

We showed that a thorough physical examination during the first few days of life detects abnormalities in $8-9 \%$ of newborn infants. Although some of these abnormalities would have been evident to the mother or midwife, we consider that most required a medical examination for their detection, confirming the examination as an effective means of child surveillance. By contrast, the value of the second medical examination is doubtful. Although $4 \cdot 4 \%(63 / 1428)$ of babies had an abnormality, $78 \%(49 / 63)$ of the findings were of minor abnormalities and $11 \%(7 / 63)$ of missed abnormalities. Failure to identify, before discharge, the three missed abnormalities requiring intervention should not have been detrimental subsequently, especially considering their nature and the continuing care given by the primary health care team. Thus only $0.5 \%$ of the examinations detected an important finding: the most notable with respect to long term implications was that of dislocatable hips.

These results show that the value of a second full neonatal examination as a medical surveillance procedure is largely limited to detecting hip abnormalities. We therefore conclude that a second thorough examination at this age cannot be justified as a screening procedure for abnormality and concur with the recommendations of the joint working party that a single detailed neonatal examination is sufficient and that a repeat examination of the hips alone towards the end of the lst week of life is necessary. The time saved would then be better used to discuss parental concerns; the care, feeding, and problems associated with normal infants; and immunisation procedures.

As $38.5 \%$ of babies are discharged on or before day 2 the second hip examination in these infants will need to be done by their general practitioner. For babies staying in hospital longer than 48 hours this examination may be performed by the hospital staff.

1 Hall DMB, ed. Health for all children. A programme for child health surveillance. Oxford: Oxford University Press, 1989

2 Maternity Services Advisory Committee. Third report to the Secretaries of State for Health and for Wales. Maternity care in action. Part III: Care of the mother and baby (postnatal and neonatal care). London: HMSO, 1985.

Accepted 13 February 1991)

\section{ONE HUNDRED YEARS AGO}

It is really very annoying that our friend the enemy will not take the trouble to understand the official view as to the status of medical officers of the British army. We all know that they are non-combatants, and that no self-respecting War Minister would ever dream of recommending them for the honours or rank which fall to the lot of those other officers who build the bridges or have charge of the baggage mules. Yet somehow or other we never have a little war or a horrible massacre but one of these medical officers is killed or wounded. It is true that, being a non-combatant, he ought not, according to the rules of war as understanded of the Horse Guards, to have been wounded or killed; and this reflection must be a great source of consolation to him or to his widow, as the case may be. It is, however, mortifying to find how backward the Manipurs are; even after enjoying the advantages of British protection for more than half a century, they have entirely failed to distinguish between the combatant and the (officially) non-combatant. One combatant officer has been killed, and, so far as appears, the only other officer touched was the only "non-combatant" officer present - Surgeon Calvert.

(British Medical fournal 1891;i:770) 